\title{
Emerging Adults' Barriers, Consideration, and Intention to do Thalassemia Screening Test as Preventive Health Behavior
}

\author{
Yasmine Parawina Larasati ${ }^{1}$, Adhityawarman Menaldi
}

Faculty of Psychology, Universitas Indonesia

\section{Submitted 02 January 2020 Accepted 27 March 2020 Published 24 August 2020}

\begin{abstract}
The number of thalassemia patients in Indonesia is predicted to rise every year. This genetic disease could cause psychological impact and large expenses for patients, families, caretakers, and the government. This study aimed to analyze the correlation between perceived barriers (PB) and consideration of future consequences ( $\mathrm{CFC}$ ), and also their interaction with behavioral intention (BI) to undergo a thalassemia screening as part of preventive health behavior (PHB). Participants were 411 young adults, aged 18 to 25 years old $(M=20.47)$. The measurements used in the study were adapted versions of PHB Scale, the CFC-14 Scale, and BI Scale. Main results from PROCESS regression analysis showed, (1) a negative and significant influence from the PB to BI $\left(b_{1}=-0.0089 ; p<0.05\right)$, (2) CFC had insignificant influence toward BI $\left(b_{2}=0.0096 ; p>0.05\right)$, (3) the interactions of PB and CFC had insignificant influence toward BI ( $\left.b_{3}=-0.0005 ; p>0.05\right)$. Self-efficacy, as controlled variable, had significant correlation with BI and became strong predictor toward the intention to enact PHB. This study concluded that barriers remain as dominant factor that determines someone's PHB. The more elaborate patient's knowledge, the more they see barriers as challenges, therefore the higher their efficacy to enact PHB.
\end{abstract}

Keywords: barriers; intention; preventive health behavior; thalassemia

Thalassemia is a genetic disease which is caused by the mutation of alpha red blood cells (alpha thalassemia) and beta red blood cells (beta thalassemia), resulting in hemoglobin deficit inside human blood (Keşkek, Kirim, Turhan, \& Turhan, 2013). According to the International Classification of Diseases $11^{\text {th }}$ Revision (ICD-11) published by the World Health Organization (WHO) in 2018, thalassemia is included in the 3A50 subcategory of erythrocytes disorder and blood formation disorder. Some countries across the Mediterranean to South East Asia have a

Address for correspondence:

yasmineparawina@gmail.com high prevalence of the beta thalassemia, including Italy, Greece, Turkey, Arab, Iran, Iraq, Indonesia, et cetera (Rathod et al., 2007). Based on the severity level, Thalassemia is categorized into three types; major thalassemia, intermedia, and minor thalassemia/carrier. Major and intermedia thalassemia patients need treatment in form of lifetime blood transfusion. They tend to show symptoms such as anemia, delayed growth and development, yellow skin, bloated stomach, and so on (Kementerian Kesehatan Republik Indonesia [Ministry of Health Republic of Indonesia], 2017). On the other hand, carrier individuals often show little to no symptoms at all 
(asymptomatic) and only experience mild anemia (Keşkek et al., 2013) so they would not be needing any form of treatments.

Hence, carriers are very likely unaware of this disease as it seems unthreatening to their lives. Unfortunately, because of this ignorance, there is greater risk for having a child with major thalassemia between carrier couples with a chance of one in four for each pregnancy (Widayanti et al., 2011). If two carriers were to have children, the probabilities were: having a child with major thalassemia $(25 \%)$, having a child as a carrier $(50 \%)$, and having a normal and healthy child (25\%) (Karimzaei et al., 2015). Yayasan Thalassemia Indonesia (YTI) stated that the prevalence of carrier individuals in Indonesia is 6 to $10 \%$. On an article covered in Lifestyle.bisnis.com, Director of Non-Communicable Diseases Management, Lily Setyowati, stated that thalassemia is currently placing fifth among non-communicable diseases; after cardiovascular disease, cancer, kidney, and stroke; which deplete government's public health funds through Badan Penyedia Jaminan Sosial (BPJS) Kesehatan; respectively.

Aside from the financial impact experienced by patients, families, and the nation, this genetic disease is also associated with mental disorders such as depression, which is often comorbid with chronic illness and this condition might worsen the individual's general health (Moussavi et al., 2007). The psychological manifestation experienced by teenagers with thalassemia (both major/intermedia or carrier) are depression and anxiety. Depression is very likely to occur in carrier individuals and their physical health might worsen with the onset of depression (Keşkek et al., 2013). Until today, there has not been any medication or treatment that could cure this genetic mutation disease, although a preventive action could be taken by avoiding marriage between carrier individuals and through thalassemia blood-test screening. The prevalence, statistic, severity level, and impact caused by this disease are the reasons why it is important to promote thalassemia screening to society.

Participating in a screening test is a form of health behavior, which is an effort voluntarily made by individuals with little to no symptoms of diseases because they believe their action could prevent them from getting sick or promote their health (Kasl \& Cobb, 1966). The health behavior in which a person takes preventive action is called as preventive health behavior (PHB). One of the models that could explain and determine an individual's PHB is called the Health Belief Model (HBM), a cognitive model most commonly used to explain a preventive behavior in medical aspects (Kirscht, 1983). Components which build HBM are the main concepts that can predict someone's intention to perform preventive behavior, to do screening, or to take control over a disease (Champion \& Skinner, 2008). They are different than the usual behavior components as they aim to predict the tendency of a specific behavior (Kirscht, 1983). Those components are susceptibility, seriousness, benefits and barriers of the behavior, and cues to action (Figure 1). 


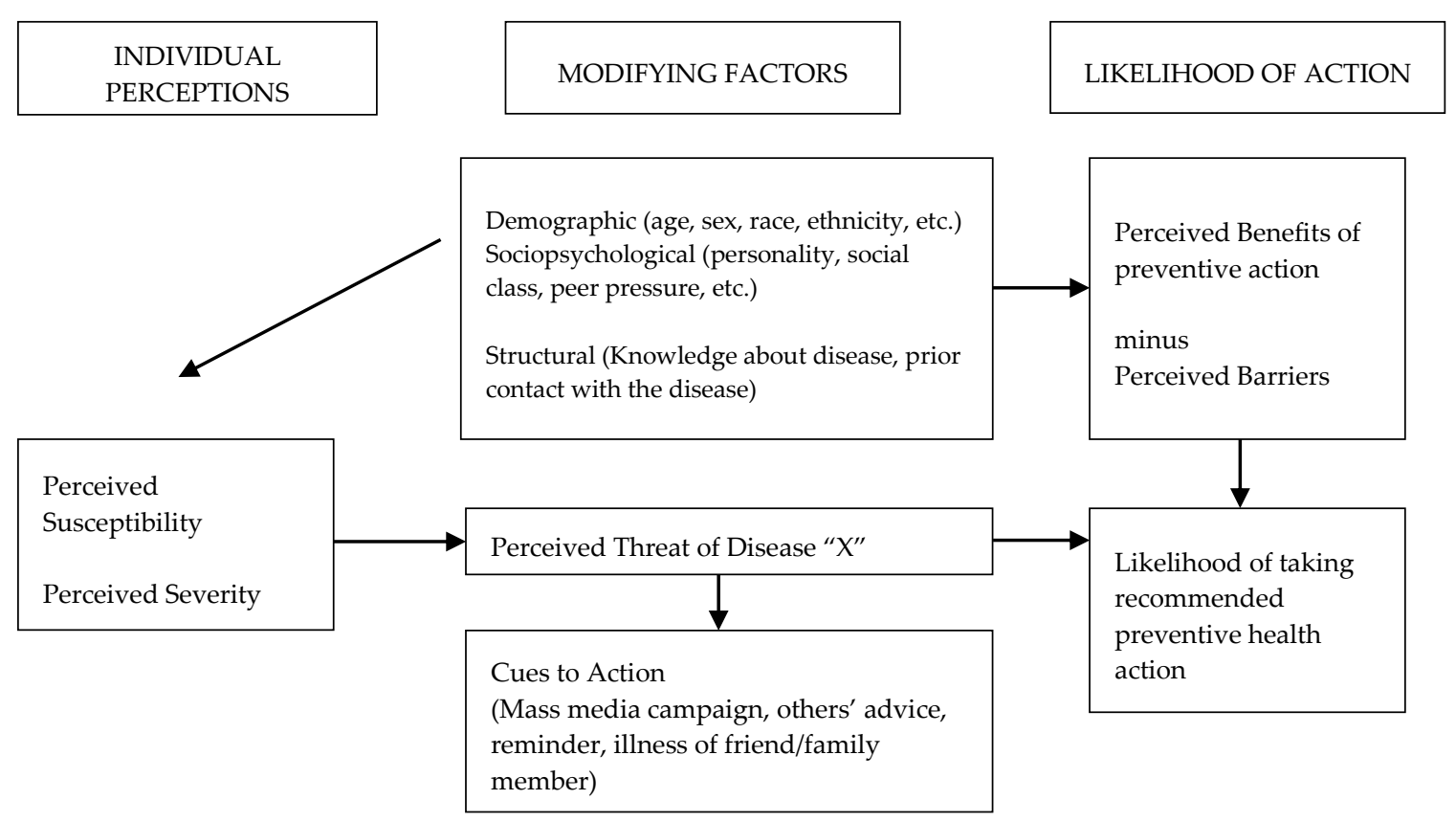

Figure 1. Health Belief Model (Rosenstock, 1974)

One of the components in HBM, barriers or perceived barriers (PB) was examined in the research about thalassemia screening toward married couples who are carriers in Iran (Karimzaei et al., 2015) which determined their intention to participate in the blood-test screening. The study found that, when a person's PB is low, s/he sees minimum barriers toward an action, which leads to higher probability for the individual to have bigger intention and thus doing a preventive health behavior (PHB). Perceived barriers is one's beliefs about the hindrances that could happen when they perform preventive behavior regarding their health condition (Champion, 1999). Some of the factors included as PB based on previous research on Pap smear screening for cervical cancer were: embarrassment, fear of pain, knowledge and awareness, attitudes, accessibility to health care service, lack of support, and time and cost (Julinawati, Cawley, Domegan, Brenner, \& Rowan, 2013). PB weighs in the biggest effect in influencing one's tendency to perform a behavior compared to the other factors in HBM (severity, susceptibility, and benefit). Meta-analysis results showed that barrier is a stronger predictor in eliciting preventive behavior than curative behavior (Carpenter, 2010). PB was also found to have significant negative correlation with intention in consuming organic food (Yazdanpanah, Forouzani, \& Hojiati, 2015).

A behavior can occur when it is preceded by behavioral intention (BI), a direct determinant from every behavior (Hill, Fishbein, \& Ajzen, 1977). Thus, BI can be used as a scale to a behavior when it has not yet been displayed. While intention itself appears as the strongest predictor to a behavior, intention is also the final product of a motivational phase in decision making (Conner \& Norman, 2015). When we see intention as a concept of an individual's intensity to start a physical activity, it becomes a great predictive factor to that behavior (Rhodes 
\& Rebar, 2017). Factors that influence BI including social support, media information, socio-economic-culture situation (Conner \& Norman, 2015) the role of health care center, and other conditions that could elicit stress (Cole, Holtgrave, \& Ríos, 2016). Because of the great influence BI has in eliciting a behavior, BI was chosen to be one of the primary foci in this research.

Another factor contributing to $\mathrm{BI}$ and PHB is the considerations that one might have of before developing an intention. Knowing that carriers might not experience the direct impact of thalassemia, we wanted to see the role of a consideration of future consequences (CFC) in influencing the individual's $\mathrm{BI}$ to do a thalassemia screening. CFC involves individual's inner struggle between the potential behavior and the outcome (usually beneficial) that might happen in short and long term (Strathman, Gleicher, Boninger, \& Edwards, 1994).

In the health psychology area, CFC is a specific concept of time orientation. It is a concept that emphasizes the cognitive function in perceiving present and future, not how the individual feels toward the present and future (Murphy \& Dockray, 2018). CFC can be broken down into CFCFuture (in the future-consequences orientation) and CFC-Immediate (soonerconsequences orientation). The relationship between CFC and PB was proven to be negatively significant, as a study showed that the higher the CFC, the lower the PB (Orji, Vassileva, \& Mandryk, 2012). In McKay and colleagues' study (2015), CFC was found to moderate the interaction between aggression and drinking behavior in females. Therefore, we predicted that CFC could have a role as a moderator in the PB and BI relationship.
Lack of knowledge about thalassemia also becomes a supporting factor for not doing blood-test screening, hence the marriage and childbirth by carrier couples (Waheed, Fisher, Awofeso, \& Stanley, 2016). But despite the knowledge about the disease, thalassemia patients are still increasing, which depicts the high number of marriages among carrier couples. Thus, the increased amount of knowledge toward a disease does not necessarily enhance one's health behavior (Baranowski, Cullen, Nicklas, Thompson, \& Baranowski, 2003; Fitzpatrick, 2011). One of the strongest constructs which was proven to be the strongest influencer to intention is self-efficacy (Janz \& Becker, 1984; Orji et al., 2012). Self-efficacy is an individual's belief that they are capable of doing and accomplishing things (Bandura, Freeman, \& Lightsey, 1999). The stronger the self-efficacy, the individual becomes more active in giving their efforts (Bandura, 1977). In this research, self-efficacy was highly considered as prominent factor in understanding the phenomenon of one's intention to execute a behavior. Hence, self-efficacy was controlled statistically so that we could look at the relationship among $\mathrm{PB}, \mathrm{CFC}$, and $\mathrm{BI}$ without the influence of self-efficacy.

With many factors determining one's intention to take action regarding a healthy behavior, we were interested to see how this would apply, especially to emerging adults, aged 18 to 25 years old, and had a higher education level. Emerging adults tend to start developing habits related to health and also interpersonal relationships including marriage. Thus, having a clearer and deeper knowledge about health becomes even more crucial (Braithwaite, Delevi, \& Fincham, 2010). Another finding suggested that there is a positively significant correlation 
between education level and health behavior, whereas the higher the education level, the more people pay attention to their health and thus enact health behavior (Pradono \& Sulistyowati, 2014).

Based on the explanation above, we would like to see how the relationship would be between PB and BI moderated by CFC if the research participants were to be given the same amount of knowledge about thalassemia. We hypothesized that the individual with high PB has smaller chance of having high BI (thus, in other words, low PHB). But when the individual has a high CFC score, which is when the individual considers future consequences to do (or not to do) screening test, the individual will have a high BI. A high CFC score was proven to be a better predictor to one's intention and health behavior. A higher CFC will influence individuals with either low or high PB to have a higher BI. In other words, CFC played as a moderating variable in this study, whereas the interaction between $\mathrm{PB}$ and $\mathrm{CFC}$ would influence the BI (Figure 2).

\section{Methods}

Emerging adults were chosen to be the participants in this study. The characteristics required from participants were: (1) understanding Indonesian language, (2) Jakarta metropolitan area (Jabodetabek) domicile, (3) aged between 18 and 25 years old, (4) at the time enrolled as diploma or undergraduate college student (D3/S1) or had obtained the diploma degree or bachelor degree, (5) not yet married, and (6) had never been screened for thalassemia.

To gather data from participants, we started by creating broadcast message shared through social media where people could access the link and register themselves. After filling the informed consent, participants with matching criteria were directed to watch a short video about thalassemia for about four minutes. The video gave information about thalassemia by definition, how it is passed down to generation, the symptoms, prevalence in Indonesia and the treatment. After the video ended, participants were given quick survey regarding their reaction toward the video. Afterwards, participants filled in the questionnaire and at the end of the study, we asked participants to voluntarily share the questionnaire through their own social media accounts to increase the awareness toward this study and gain more participants. By sharing the link to this questionnaire, whoever met the criteria was eligible to participate in this study.

Perceived barriers was measured by using the adaptation instrument which assessed five dimensions of HBM in the context of colorectal cancer screening through blood stool test (Tahmasebi, Noroozi, \& Dashdebi, 2016). Based on the Cronbach Alpha technique, this instru-

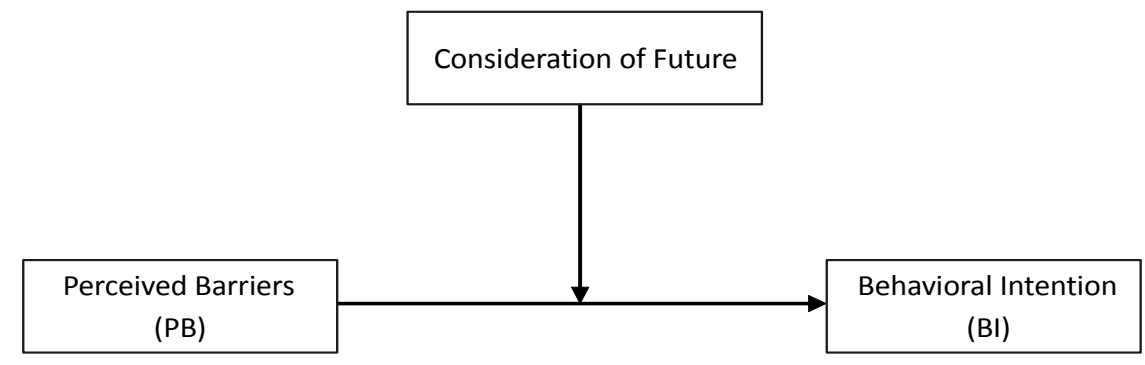

Figure 2. Research model 
ment reached coefficient alpha of 0.71 , or internally consistent in measuring a construct (significant at $\operatorname{LoS}=0.05$ ). Therefore, this instrument was considered reliable. We aimed to measure PB through the items that have coefficient alpha of 0.73, which is considered reliable or internally consistent to measure PB. The PB measurement tool had $73 \%$ variant of true score from the observed score, and $23 \%$ variant of error score. Validity of the instrument was measured through internal consistency with a benchmark of $r>0.2$ (Nunnaly \& Bernstein, 1994). The validity of this tool was tested separately by dimension because it was a multidimensional measurement tool $(r=-0.24-0.574)$. The items that scored negative were eliminated, resulting in 14-item PB measurement. Therefore, this instrument was considered valid. This measurement used a 5-Likert scale (1 = strongly disagree; $5=$ strongly agree).

Behavioral Intention was measured by using a single-item question because a construct that is concrete and nonambiguous can be presented using one item (Wanous, Reichers, \& Hudy, 1997) and intention is a strong and concrete construct in predicting a behavior outcome (Hubbard et al., 2018). In this research, the BI single-item measure was: “Seberapa besar Anda berniat untuk melakukan skrining/tes darah Thalasemia?" ("How much do you intend to do the Thalassemia screening test?"). This tool was measured by using 5Likert scale ( $1=$ very unlikely; $5=$ very likely).

In this research, consideration of future consequences (CFC) measurement was adapted from the CFC-14 Scale (Joireman, Shaffer, Balliet, \& Strathman, 2012), with coefficient alpha of 0.829 . The validity test for this measurement showed $r=0.175-0.755$. This measurement was considered reliable and valid and scored using the 5-Likert Scale, in which the higher participants score in that item, the more that item is best described. The items that represent CFC-Future are considered as the favorable items while the items that represent CFC-Immediate are considered as unfavorable, thus making the scoring technique to be reversed for unfavorable items.

Self-efficacy was measured using the same tool that measured PB. In the measurement tool, self-efficacy was measured through 6 items with coefficient alpha of $0.653 ; r=-0.087-0.675$. The item that obtained negative score was eliminated, leaving only 5 items. This measurement was considered reliable and valid.

A descriptive statistic was used to capture the overview of research participants based on their demographics. The data consisted of initial, gender, institution and the major of study, profession, residence, relationship status (single/in a romantic relationship), and their contact number if they wished to be given a reward. The descriptive data were processed using IBM SPSS v.20. We analyzed the moderation by controlling one variable as a covariate, using the PROCESS Macro model 1 v.3.2, the extension software for mediation and moderation (Hayes, 2013). By using the moderation Model 1 or the simple moderation, we attained a regression result between $\mathrm{PB}$ and $\mathrm{BI}$ ( $b_{1}$ relationship), $\mathrm{CFC}$ and $\mathrm{BI}$ ( $b_{2}$ relationship), and the interaction of $\mathrm{PB}$ and $\mathrm{CFC}$ toward $\mathrm{BI}\left(b_{3}\right.$ relationship).

\section{Results}

From 422 participants who filled in the online questionnaire, 10 participants did 
not meet the criteria and thus did not proceed with the study. The other 1 participant did not complete the survey and thus was not included. After conducting data cleansing, 411 participants were included in the research, all had consented to participate in the research, and met the criteria, which were in the age range of $18-25$ years old $(M=$ 20.47; $S D=1.81)$. Based on Table $1,72 \%$ of the participants were female $(\mathrm{N}=296)$. There are $95.1 \%$ participants $(\mathrm{N}=393)$ who had either already completed their study or at that time enrolled in a Bachelor's degree program.

Table 1 shows the overall result of all variables in this research. For the predictor variable (PB), the lowest score from 411 participants was 14 while the highest score was 70 out of $70(M=41.52$; $S D=8.36)$. This result means that participant responses were varied in which there were participants who had the lowest to no barrier to do thalassemia screening and there were others who had the highest barrier to do it. With the average score of 41.52, participants in this research had a low score in PB or perceived minimum amounts of barriers to do thalassemia screening.

Similar result happens to the outcome variable (BI), with the lowest score 1 out of 5 and the highest score 5 out of $5(M=3.84$; $S D=0.88)$. Participants' responses varied from very unlikely to very likely to have intention to do the screening. In this research, the result of participants' average responses showed that participants had a quite high intention to do thalassemia screening.

The moderating variable (CFC) attained 25 as the minimum score and 69 out of 70 as the maximum score $(M=48.62$; $S D=6.46)$. This result showed that participant responses varied as well. However, the average score attained was 48.62 and therefore is considered as a high CFC score. Thus, the average participants

Table 1.

Participants Based on Demographic Data

\begin{tabular}{llcc}
\hline \multicolumn{2}{c}{ Demographic Aspects } & $\begin{array}{c}\text { Frequency } \\
\mathbf{( N = 4 1 1 )}\end{array}$ & $\begin{array}{c}\text { Percentage } \\
\mathbf{( \% )}\end{array}$ \\
\hline \multirow{2}{*}{ Gender } & Male & 108 & 26.3 \\
& Female & 296 & 72 \\
& Prefer Not to Say & 7 & 1.7 \\
\multirow{3}{*}{ Last/Current Education Level } & Bachelor's & 393 & 95.6 \\
& Diploma (D3) & 18 & 4.4 \\
\hline \multirow{2}{*}{ Total } & & 411 & 100 \\
\hline
\end{tabular}

Table 2.

Overall Descriptive Results

\begin{tabular}{lllllll}
\hline \multicolumn{1}{c}{ Variable } & N item & \multicolumn{1}{c}{ Min. } & \multicolumn{1}{c}{ Max. } & Mean & \multicolumn{1}{c}{ SD } & N \\
\hline Perceived Barriers & 14 & 14.00 & 70.00 & 41.5207 & 8.3603 & 411 \\
Behavioral Intention & 1 & 1.00 & 5.00 & 3.8418 & .8872 & 411 \\
$\begin{array}{l}\text { Consideration of Future } \\
\text { Consequences }\end{array}$ & 14 & 25.00 & 69.00 & 48.6204 & 6.4673 & 411 \\
\hline
\end{tabular}


in this research had a high score in considering the future consequences of doing thalassemia screening. Overall descriptive results are shown in Table 2.

The variables were analyzed using PROCESS Hayes Model No. 1 which is suitable to analyze a research with moderator regression model, since this macro tool generates table. Thus, it is able to focus on testing the interaction of independent variable and moderating variable effect toward the dependent variable, as well as having another variable as covariate (Hayes, 2018). In this analysis, the self-efficacy (SE) variable was controlled statistically. Based on the RSquare $\left(R^{2}\right)$ analysis (shown in Table 3), the result showed $R^{2}$ score $=0.34$. This means that there was $34 \%$ score variance in $\mathrm{BI}$ variable that could be explained by $\mathrm{PB}$ variables with $\mathrm{CFC}$ as moderating variables. Based on this regression analysis, we found three main results. First, PB had a significant negative correlation with BI $(t=-2.019 ; p<0.05)$. This result was aligned with what we had hypothesized. Second, there was no significant correlation between CFC and BI $(t=-1.639 ; p>0.05)$. Third, the interaction between PB and CFC and its correlation with BI showed no significant result $(t=$ $0.808 ; p>0.05)$. Therefore, this research could not capture the relationship among these variables as we had hypothesized. Based on Figure 3, the result in this research did not show any moderation between $\mathrm{PB}$ and $\mathrm{CFC}$ toward $\mathrm{BI}$.

Table 3.

Regression Analysis Result with CFC as Moderating Variable to the Relation between Perceived Barriers and Behavioral Intention

\begin{tabular}{|c|c|c|c|c|c|c|}
\hline \multirow{2}{*}{ Model } & \multicolumn{2}{|c|}{ Unstandardized Coefficients } & \multirow{2}{*}{$\mathbf{t}$} & \multirow{2}{*}{$\mathbf{P}$} & \multicolumn{2}{|c|}{ 95\% Confidence Interval } \\
\hline & $\mathrm{b}$ & $\mathrm{Se}$ & & & LLCI & ULCI \\
\hline Constant & .6524 & .2537 & 2.571 & .0105 & .1536 & 1.1512 \\
\hline $\mathrm{PB}$ & -.0089 & .0044 & -2.019 & .0441 & -.0176 & -.0002 \\
\hline CFC & .0096 & .0059 & 1.639 & .1019 & -.0019 & .0211 \\
\hline PB $\times$ CFC Covariate & -.0005 & .0006 & -.8085 & .4193 & -.0018 & .0007 \\
\hline SE & .1296 & .0103 & 12.632 & .0000 & .1094 & .1498 \\
\hline
\end{tabular}

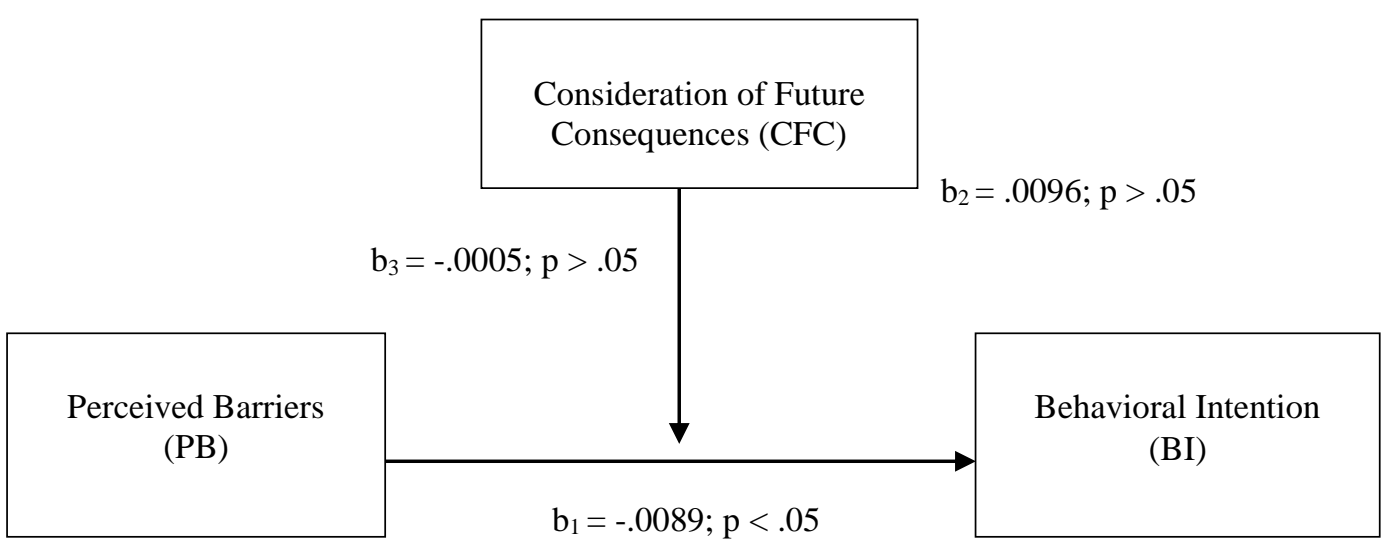

Figure. 3. Moderating analysis result 
The effect size in this research is considered as a large effect, with $f^{2}=0.52$. Effect size score that is bigger than 0.35 ( $f^{2}$ $>0.35)$ is considered to be a large effect (Faul, Erdfelder, Lang, \& Buchner, 2007). Another finding showed that SE as the covariate variable had a significant and positive correlation to $\mathrm{BI}(t=11.38 ; p<$ $0.05)$. Thus, as the theory said, SE is a strong predictor to BI. Therefore, it was being controlled to avoid SE influencing the interaction among other three variables.

\section{Discussion}

Several results are consistent with the previous literatures about health behavior and the components in HBM. The significant result in this research once again supports previous research findings and theory about HBM, whereas the bigger the barriers someone perceives, the more reluctant someone to perform a healthy behavior (Rosenstock, 1974). This finding is also supported by the findings in Iran about $\mathrm{PB}$ as the primary reason married couples did not want to conduct thalassemia screening (Karimzaei et al., 2015).

The kind of barriers that received high response from participants were the barrier to information (not knowing about thalassemia), time availability, and emotion (fear of discovering) respectively. This finding supports that knowledge has a big influence for people to do prevention. Based on the participants' responses, the information about thalassemia as well as its treatment and prevention provided by health services is minimal. This implied that if we were to hold a public event for thalassemia screening and psychoeducation, it might boost people intention in doing screening test. Participants also had high responses to the item that stated they would forget to do screening test, meaning that doing a thalassemia screening or a preventive behavior is not their top priority. Similar to this study was a survey in which: $18.1 \%$ participants answered that ignorance was the barrier to do a preventive behavior, $17.2 \%$ was of the lack of health services availability, $10.2 \%$ was the barrier to time availability, and the other $25 \%$ answered with a variety of responses related to PB (Jacobson \& Madsen, 2016).

Another main finding in this study was that there is no significant correlation between the moderating variable, CFC, and the outcome variable, BI. In this study, CFC was found to have no relationship with BI, although many studies about CFC in this field had proven that CFC is influences individual's health behavior. This finding contrasts with the study discussing the significant relationship between CFC and participant's intention to quit smoking (Kovač \& Rise, 2007). Responses of participants with CFC-F (scored high on CFC) and participants with CFC-I (scored low on CFC) toward the item that measured $\mathrm{BI}$, might be the cause of insignificant result in this study. The general responses toward BI were not so varied among the participants, where we once assumed that participants with CFC-F would have a higher score of BI than participants with CFC-I.

Nevertheless, this study showed that participants in both categories tend to score 3 to 5 on the BI item. This unique finding will be discussed in two rationales. First, the influence of CFC itself depends on a social context (Demarque, Apostolidis, \& Joule, 2013). If we look at the study method, information about thalassemia was given to all participants through an animated video. The video 
included an explanation about thalassemia, its symptoms, heredity structure, and the invitation to start doing the screening test. The information was delivered in quite a short time, which was about 4 minutes, thus influencing participants' CFC. This process is actually similar to a study of temporal framing (Kees, Burton, \& Tangari, 2010; Orbell \& Hagger, 2006).

A person with CFC-I tends to be more interested in information or invitation that gives an immediate experience of positive outcomes (Kees, 2010; Orbell, Perugini, \& Rakow, 2004). There might be a chance that participants with CFC-I (low on CFC score) have high intention to do thalassemia screening because they could gain an immediate benefit and not because they think about the benefits in the future. In health psychology, perceived susceptibility and perceived severity (which lie in the same category, perceived threat) also play a role in shaping one's preventive health behavior (PHB). Information about thalassemia, though delivered in an elaborate way, might be novel and unfamiliar to participants. The current and new information became an intriguing new knowledge for participants, driving them to wanting to conduct screening. Framing information that exposed the consequences (whether positive or negative) in a short moment could help consumers who initially did not consider the future consequences to give a thought about it (Kees, 2010). The insignificant result in this study might occur because the message delivered in this study was considered as new and very informative, thus increasing the participants' intention to do a specific behavior (Kim \& Nan, 2016), which was thalassemia screening.

Second, the dictions chosen to create the BI single item scale might cause certain limitations as to why the average participant response was quite high, which was between 3 and 5 out of 5 . The sentence sounded as: "Seberapa besar Anda berniat untuk melakukan skrining/tes darah Thalasemia?" ("How much do you intend to do a Thalassemia blood screening?"). The word "berniat" or "intend" might generate a different perception to participants, whereas to some (if not all) the word "intend" was still perceived as only a plan or interest, even though theoretically intention as a construct is considered as a strong predictor of an enacted behavior. We assumed that if the word "intend" was replaced with "would do" ("akan melakukan"), it might elicit a more specific response toward the BI variable. Adding a time frame into the BI item is also essential to prime participants' specific and more concrete responses. Thus, the better version of this BI single item would be: "Seberapa besar Anda berniat untuk melakukan skrining/tes darah Thalasemia dalam $X$ hari/minggu/bulan/tahun ke depan?" ("How likely would you do a thalassemia blood screening in the following X day/week/month/year?").

One of the things that could cause PB and CFC interaction toward BI showed no significant result was the lack of data about participants' knowledge regarding thalassemia prior to this study. We assume that their responses to the items can be influenced by their prior knowledge of thalassemia. There might be a chance that some of the participants had heard about thalassemia before, or they might have family, friends, or relatives that suffer from thalassemia without knowing their own blood status. The prior knowledge about thalassemia can influence the perceived susceptibility and perceived severity dimensions, thus influencing their overall response. Because we did not 
control the other variables measured in the PB scale (perceived susceptibility, perceived severity, and perceived benefits), participant responses toward the BI variable could also be influenced, therefore the data in this study might be mixed.

The presence of relatively high valued sweepstakes reward or the instant prizes offered to participants by only completing all questionnaire items could also influence participants' earnestness and seriousness in proceeding with the research. There might be a chance that participants did not respond truthfully because they were eyeing the prize once they completed the questionnaire. Nevertheless, from the total participants $(\mathrm{N}=411)$, only 11 who did not watch the video until the end, indicating that at least about 400 participants did receive the full and elaborate information about thalassemia. Additionally, self-efficacy showed a significant result even though it was being controlled statistically. Once again, selfefficacy proves its big role in influencing one's intention.

\section{Conclusion}

This study aimed to look at the psychological factors in emerging adult population in doing preventive health behavior (PHB). In this study, the context chosen was thalassemia prevention to the next generation by blood-test screening to identify whether a person is a carrier. there were several findings based on this research analysis.

First, the relationship between the predictor variable, perceived barriers (PB), and the outcome variable, behavioral intention (BI), in doing a thalassemia screening among emerging adults showed a negative significant correlation. In other words, the bigger barriers that someone perceives to do screening, the smaller their intention to do screening test. Second, the relationship between moderating variable, consideration of future consequences (CFC), and BI were not significant. It means that the consideration one has of either future or immediate consequences of one's behavior does not correlate to one's intention to do screening. Third, the interaction of the predictor variable and the moderating variable, $\mathrm{PB}$ and $\mathrm{CFC}$, was not correlated with the outcome variable, BI. This means that in this research, CFC could not be used to explain the relationship between PB and BI. The finding in this research showed that in the emerging adult population, the perception of barriers will still exist, but in the end the individual's self-efficacy can play a big factor in influencing one's intention to actually perform preventive behavior. Therefore, intervention programs should not only provide information by exposing the negative and positive consequences, along with cultivating fear (fear appeal) or daunting them with the negative consequences of having to live with thalassemia. It also needs to be able to increase people's self-efficacy.

However, this study has several limitations. First, conducting an experimental study will specify the result because causal relationship of the variables can be examined. In an experimental study, more variables can be controlled to attain a clearer result of the measured variables. The role of video animation as a source of information can also be more influential in an experimental setting. Secondly in the future study, the study method, such as choosing and adapting instruments, must be designed better. Thirdly, this study only examined on one construct of HBM, which is perceived barriers as an independent variable. 
Lastly, this study was limited to Jakarta metropolitan area, which means it did not represent overall data of Indonesia.

\section{Suggestion}

The number of studies about health behavior and the individual psychological aspects toward thalassemia, specifically in Indonesia, needs to be increased. The results from this research, along with other similar ones, can be used as references to design an intervention program to society about this genetic disease. To gain more elaborate result, it is better to conduct an experimental study or a mixed method study which combines quantitative and qualitative approaches.

The CFC construct as a moderating variable can be examined further by studying the differences between CFCFuture and CFC-Immediate in influencing health behavior or other psychological aspects. CFC can be measured using more specific tool for CFC in the health context or preventive health behavior context. Until today, there are several CFC scales with a specific context such as CFCExercise and CFC-Food to measure CFC in healthy eating behavior and in exercising (van Beek, Antonides, \& Handgraaf, 2013). Research examining other dimensions in HBM can also be conducted to gain more elaborate results about participants' perceptions toward thalassemia prevention. There should also be several filtered questions as a form of control when research only involves one of the dimensions, to prevent mixed data. Lastly, intervention programs or preventive actions must also develop people's selfefficacy in taking preventive health behavior.

\section{Acknowledgments}

We thank our colleagues from University of Indonesia who provided insights and expertise that greatly assisted the research, although they may not agree with all of the interpretations/conclusions of this paper. We thank Sali Rahadi Asih, M. Psi., MGPCC, Ph.D., Psikolog and Nurul Arbiyah, M. Si., for assistance and comments that greatly improved the manuscript. We would also thank Endro Kustono, creator of Thalassemia animated video who had granted the permission for us to use the video for this study. We are also immensely grateful to fellow presenters and lecturers from Universitas Gadjah Mada, Yogyakarta during the ICICP 2019 for their inputs on an earlier version of the manuscript, although any error is our own and should not tarnish the reputations of these esteemed persons.

\section{Funding}

This study was not funded by any funding program

\section{Authors' contributions}

YPL conducted literature study, arranged proposal, drafted manuscript, conducted data gathering, and ran statistical analysis; AM conducted literature study, analyzed the result, refined conclusions, and finalized the manuscript.

\section{Conflict of interest}

We declare there is no conflict of interest in this research

\section{Orcid id}

Adhityawarman Menaldi. 0000-0003-3755-0770

\section{References}

Bandura, A. (1977). Self-efficacy: Toward a unifying theory of behavioral change. Psychological Review, 84(2), 191-215. doi: 10.1037/0033-295X.84.2.191 
Bandura, A., Freeman, W. H., \& Lightsey, R. (1999). Self-efficacy: The exercise of control. Journal of Cognitive Psychotherapy, 13(2), 158-166. doi: $\underline{10.1891 / 0889-8391.13 .2 .158}$

Baranowski, T., Cullen, K. W., Nicklas, T., Thompson, D., \& Baranowski, J. (2003). Are current health behavioral change models helpful in guiding prevention of weight gain efforts? Obesity Research, 11(S10), 23S-43S. doi: 10.1038/oby.2003.222

Braithwaite, S. R., Delevi, R., \& Fincham, F. D. (2010). Romantic relationships and the physical and mental health of college students. Personal Relationships, 17(1), 1-12. doi: 10.1111/j.1475-6811.2010.01248.x

Carpenter, C. J. (2010). A meta-analysis of the effectiveness of health belief model variables in predicting behavior. Health Communication, 25(8), 661-669. doi: $\underline{10.1080 / 10410236.2010 .521906}$

Champion, V. L. (1999). Revised susceptibility, benefits, and barriers scale for mammography screening. Research in Nursing and Health, 22(4), 341-348. doi: 10.1002/(SICI)1098240X(199908)22:4<341::AID-

NUR8>3.0.CO;2-P

Champion, V. L., \& Skinner, C. S. (2008). The health belief model. In K. Glanz, B. K. Rimer, \& K. Viswanath (Eds.), Health behavior and health education: Theory, research, and practice (p. 45-65). San Francisco, CA: Jossey-Bass.

Cole, G. E., Holtgrave, D. R., \& Ríos, N. M. (2016). Internal and external factors that encourage or discourage health-relevant behaviors. Retrieved from https://www.orau.gov/cdcynergy/soc 2web/Content/activeinformation/reso urces/Health_Behavior_Factors.pdf

Conner, M., \& Norman, P. (2015). Predicting and changing health behavior:

\section{Research and}

practice with social cognition models (3rd ed.). New York, NY: McGraw-Hill.

Demarque, C., Apostolidis, T., \& Joule, R. V. (2013). Consideration of future consequences and pro-environmental decision making in the context of persuasion and binding commitment. Journal of Environmental Psychology, 36, 214-220. doi: 10.1016/j.jenvp.2013.07.019

Faul, F., Erdfelder, E., Lang, A. G., \& Buchner, A. (2007). G*Power 3: A flexible statistical power analysis program for the social, behavioral, and biomedical sciences. Behavior Research Methods, 39, 175-191. doi: $\underline{10.3758 / B F 03193146}$

Fitzpatrick, S. L. (2011). Health knowledge \& health behavior outcomes in adolescents with elevated blood pressure. ProQuest Dissertations and Theses, 97. Retrieved from http://search.proquest.com.ezproxy.li brary.yorku.ca/docview/887719226?ac countid=15182\%5Cnhttp://sfx.scholar sportal.info/york?url_ver=Z39.88-

2004\&rft_val_fmt=info:ofi/fmt:kev:mt $\mathrm{x}$ :dissertation \&genre $=$ dissertations $+\&$ +theses\&sid=ProQ:ProQuest+Disserta tions $+\&+\mathrm{T}$

Hayes, A. F. (2013). Introduction to mediation, moderation, and conditional process analysis: $A$ regression-based approach. New York, NY: Guilford Press.

Hayes, A. F. (2018). Introduction to mediation, moderation, and conditional process analysis: A regression-based approach (2nd ed.). New York, NY: Guilford Press.

Hill, R. J., Fishbein, M., \& Ajzen, I. (1977). Belief, attitude, intention and behavior: An introduction to theory and research. Contemporary Sociology, 6(2), 244-245. doi: 10.2307/2065853 
Hubbard, G., Kyle, R. G., Neal, R. D., Marmara, V., Wang, Z., \& Dombrowski, S. U. (2018). Promoting sunscreen use and skin selfexamination to improve early detection and prevent skin cancer: Quasi-experimental trial of an adolescent psycho-educational intervention. BMC Public Health, 18, 666. doi: 10.1186/s12889-018-5570-y

Jacobson, M., \& Madsen, H. (2016). Perceived barriers to preventive screenings by individuals 18 years and older with health insurance [MSN, Clarion and Edinboro Universities]. Retrieved from https://search.proquest.com/openvie w/fdaadac75a6a5856a7a2cf1c71e768ca L1?pq-

origsite $=$ gscholar $\& \mathrm{cbl}=18750 \&$ diss $=\mathrm{y}$

Janz, N. K., \& Becker, M. H. (1984). The health belief model: A decade later. Health Education \& Behavior, 11(1), 147. doi: $10.1177 / 109019818401100101$ Joireman, J., Shaffer, M. J., Balliet, D., \& Strathman, A. (2012). Promotion orientation explains why futureoriented people exercise and eat healthy: Evidence from the two-factor Consideration of Future Consequences-14 Scale. Personality and Social Psychology Bulletin, 38(10), 1272-1287. doi:

\section{$\underline{10.1177 / 0146167212449362}$}

Julinawati, S., Cawley, D., Domegan, C., Brenner, M., \& Rowan, N. J. (2013). A review of the perceived barriers within the health belief model on Pap smear screening as a cervical cancer prevention measure. Journal of Asian Scientific Research, 3(6), 677-692.

Karimzaei, T., Masoudi, Q., Shahrakipour, M., Navidiyan, A., Jamalzae, A. A. 1. Q., \& Zoraqi Bamri, A. (2015). Knowledge, attitude and practice of carrier thalassemia marriage volunteer in prevention of major thalassemia. Global Journal of Health Science, 7(5), 364-370. doi: 10.5539/gjhs.v7n5p364

Kasl, S. V., \& Cobb, S. (1966). Health behavior, illness behavior, and sick role behavior. I. Health and illness behavior. Archives of Environmental Health, 12(2), 246-266. doi: $\underline{10.1080 / 00039896.1966 .10664365}$

Kees, J. (2010). Temporal framing in health advertising: The role of risk and future orientation. Journal of Current Issues and Research in Advertising, 32(1), 33-46. doi: $\underline{10.1080 / 10641734.2010 .10505273}$

Kees, J., Burton, S., \& Tangari, A. H. (2010). The impact of regulatory focus, temporal orientation, and fit on consumer responses to health-related advertising. Journal of Advertising, 39(1), 19-34. doi: 10.2753/JOA0091$\underline{3367390102}$

Kementerian Kesehatan Republik Indonesia. (2017). Pedoman pengendalian penyakit thalassemia di fasilitas kesehatan tingkat pertama. Jakarta: Kementerian Kesehatan Republik Indonesia.

Keşkek, Ş. Ö., Kırım, S., Turhan, A., \& Turhan, F. G. (2013). Depression in subjects with beta-thalassemia minor. Annals of Hematology,92, 1611-1615. doi: 10.1007/s00277-013-1851-9

Kim, J., \& Nan, X. (2016). Effects of consideration of future consequences and temporal framing on acceptance of the HPV vaccine among young adults. Health Communication, 31(9), 1089-1096.

doi: $\underline{10.1080 / 10410236.2015 .1038774}$

Kirscht, J. P. (1983). Preventive health behavior: A review of research and issues. Health Psychology, 2(3), 277301. doi: $10.1037 / 0278-6133.2 .3 .277$

Kovač, V. B., \& Rise, J. (2007). The relation 
between past behavior, intention, planning, and quitting smoking: The moderating effect of future orientation. Journal of Applied Biobehavioral Research, 12(2), 82-100. doi: 10.1111/j.1751-9861.2007.00015.x

McKay, M. T., Dempster, M., \& Mello, Z. (2015). Does consideration of future consequences moderate the relationship between aggression and alcohol use in adolescents? Results from the United Kingdom. Addiction Research \& Theory, 23(5), 372-379. doi: $\underline{10.3109 / 16066359.2015 .1009830}$

Moussavi, S., Chatterii, S., Verdes, E., Tandon, A., Patel, V., \& Ustun, B. (2007). Depression, chronic diseases, and decrements in health: Results from the World Health Surveys. Lancet, 370(9590), 851-858. doi: 10.1016/S0140-6736(07)61415-9

Murphy, L., \& Dockray, S. (2018). The consideration of future consequences and health behaviour: A metaanalysis. Health Psychology Review, 12(4), 357-381. doi: $\underline{10.1080 / 17437199.2018 .1489298}$

Nunnaly, J. C., \& Bernstein, I. H. (1994). Psychometry theory (3rd ed.). New York, NY: McGraw-Hil.

Orbell, S., \& Hagger, M. (2006). Temporal framing and the decision to take part in type 2 diabetes screening: Effects of individual differences in consideration of future consequences on persuasion. Health Psychology, 25(4), 537-548. doi: 10.1037/0278$\underline{6133.25 .4 .537}$

Orbell, S., Perugini, M., \& Rakow, T. (2004). Individual differences in sensitivity to health communications: Consideration of future consequences. Health Psychology, 23(4), 388-396. doi: 10.1037/02786133.23.4.388

Orji, R., Vassileva, J., \& Mandryk, R.
(2012). Towards an effective health interventions design: An extension of the health belief model. Public Health Informatics, 4(3), 1-31. doi: 10.5210/ojphi.v4i3.4321

Pradono, J., \& Sulistyowati, N. (2014). Hubungan antara tingkat pendidikan, pengetahuan tentang kesehatan lingkungan, perilaku hidup sehat dengan status kesehatan studi korelasi pada penduduk umur $10-24$ tahun di Jakarta Pusat. Buletin Penelitian Sistem Kesehatan, 17(1), 8995. Retrieved from https://media.neliti.com/media/public ations/20885-ID-correlation-betweeneducation-level-knowledge-ofenvironmental-health-healthy-be.pdf

Rathod, D. A., Kaur, A., Patel, V., Patel, K., Kabrawala, R., Patel, V., Patel, M., \& Shah, P. (2007). Usefulness of cell counter-based parameters and formulas in detection of $\beta$ thalassemia trait in areas of high prevalence. American Journal of Clinical Pathology, 128(4), 585-589. doi: 10.1309/R1YL4B4BT2WCQDGV

Rhodes, R. E., \& Rebar, A. L. (2017). Conceptualizing and defining the intention construct for future physical activity research. Exercise and Sport Sciences Reviews, 45(4), 209-216. doi: 10.1249/JES.0000000000000127

Rosenstock, I. M. (1974). Historical origins of the health belief model. Health Education Monographs, 2(4), 328-335. doi: $10.1177 / 109019817400200403$

Strathman, A., Gleicher, F., Boninger, D. S., \& Edwards, C. S. (1994). The consideration of future consequences. Journal of Personality and Social Psychology, 66(4), 742-752. doi: 10.1037/0022-3514.66.4.742

Tahmasebi, R., Noroozi, A., \& Dashdebi, K. G. (2016). Psychometric evaluation of the Colorectal Cancer Screening 
Belief Scale based on health belief model's constructs for the fecal occult blood test. Asian Pacific Journal of Cancer Prevention, 17(1), 225-229. doi: 10.7314/APJCP.2016.17.1.225

van Beek, J., Antonides, G., \& Handgraaf, M. J. J. (2013). Eat now, exercise later: The relation between consideration of immediate and future consequences and healthy behavior. Personality and Individual Differences, 54(6), 785-791. doi: 10.1016/j.paid.2012.12.015

Waheed, F., Fisher, C., Awofeso, A. N., \& Stanley, D. (2016). Carrier screening for beta-thalassemia in the Maldives: Perceptions of parents of affected children who did not take part in screening and its consequences. Journal of Community Genetics, 7, 243253. doi: $10.1007 / \mathrm{s} 12687-016-0273-5$

Wanous, J. P., Reichers, A. E., \& Hudy, M. J. (1997). Overall job satisfaction: How good are single-item measures? Journal of Applied Psychology, 82(2),
247-252. doi: $\quad \underline{10.1037 / 0021-}$ $\underline{9010.82 .2 .247}$

Widayanti, C. G., Ediati, A., Tamam, M., Faradz, S. M. H., Sistermans, E. A., \& Plass, A. M. C. (2011). Feasibility of preconception screening for thalassemia in Indonesia: Exploring the opinion of Javanese mothers. Ethnicity and Health, 16(4-5), 483-499. doi: $\underline{10.1080 / 13557858.2011 .564607}$

World Health Organization (WHO). (2018). International Classification of Diseases 11th Revision (ICD-11). Retrieved from https://www.who.int/classifications/ic d/en/

Yazdanpanah, M., Forouzani, M., \& Hojjati, M. (2015). Willingness of Iranian young adults to eat organic foods: Application of the Health Belief Model. Food Quality and Preference, 41, 75-83. doi: $\underline{10.1016 / j . f o o d q u a l .2014 .11 .012}$ 